\title{
Social context and literature sociological functions in the novel about you by tere liye
}

\author{
Meirysa $\mathbf{S}^{1}$, Ratu Wardarita ${ }^{1}$ \\ ${ }^{1}$ Universitas PGRI Palembang, Indonesia
}

\begin{tabular}{l}
\hline Article Info \\
\hline Article history: \\
Received Jul16, 2021 \\
Revised Aug $12^{\text {th }}, 2021$ \\
Accepted Aug $30^{\text {th }}, 2021$ \\
\hline
\end{tabular}

\section{Keyword:}

Social context

Socio-cultural elements

Novels about you

Literary sociology

\begin{abstract}
The purpose of this study was to describe the author's social context and sociocultural elements in the novel About You by Tere Liye. This research was a qualitative research with sociology of literature approach. This research was to describe author's social context and socio-cultural elements in the novel About You by Tere Liye. The results of the discussion in this study were obtained story fact that related to their social values namely violence, starting a business, product marketing, malaria events (January 15 disasters), friendship, and betrayal. While the social values contained in the novel About You by Tere Liye included: patience, obedience, forgiveness, helping others, caring for others, working hard, loyalty, mutual trust between friends, help between friends, and honestly. The results of this study conclude: (1) author's social context of the novel About You by Tere Liye work consists of the theme and facts of theory, and (2) socio-cultural elements of the novel About You the moral values contained in Tere Liye's novel About You are: (a) human relationships with self that include fear, death, longing and revenge, (b) human relationships with humans.
\end{abstract}

(C) 2021 The Authors. Published by IICET.

This is an open access article under the CC BY-NC-SA license

(https://creativecommons.org/licenses/by-nc-sa/4.0

\section{Corresponding Author:}

Meirysa, S.,

Universitas PGRI Palembang, Indonesia

Email: meirysas0205@gmail.com

\section{Introduction}

Literary work is a form of a person's ideas through views of the social environment around him using beautiful language. Literature exists as an author's reflection on existing phenomena. Literary works generally contain problems surrounding the author. These problems can be problems faced by the author or problems faced by other people who are appointed by the author into a literary work. One of the literary works that the author has appointed into a story is a novel. Literary works have various motorcycle taxis in their studies, for example in social life. Literary works such as novels have many characteristics through these characteristics that can divert works that can be enjoyed by many genres and many readers.

Literary work exists as a creative imaginative manifestation of a writer with different processes between one author and another, especially in the creation of fictional stories. The process is individualistic, meaning that the methods used by each author can be different, the differences include several things including methods, the emergence of the creative process and how to express what is in the author to the language used in the delivery [1]. One form of literary work that plays an important role in providing a viewpoint on life is novel. According to Waluyo [2] the novel tells the various problems of human life in their interactions with others and their environment, as well as their interactions with themselves and God. Based on this opinion, 
researchers are motivated to make literary works as research objects and examine the extent to which literary works can reflect real life and the extent to which society's relationship with a literary work is viewed from the perspective of the reader.

From the above opinion, it can be understood that reading literature works means the life and culture that prevails in a society. Besides being the result of imagination, literary works are also the author's appreciation of society. One thing that cannot be denied is the fact that an author always lives in a social environment. What he sees and feels is indirectly reflected in his works. It is not impossible for these works to immediately become a picture (reflection) of the social and cultural conditions of the community at a certain time.

Sociology of literature is a branch of literature that examines problems in literature, which includes aspects of economics, politics, traditions, morals, ethics, love, relationships, etc. is one of the topics of literature sociology. In literature, it is told about the various kinds of life that are closely related to one human being, so that it can be seen that sociology and literature actually have the same common ground. All literary facts imply the existence of writers, books and readers, or in general it can be said: creators, works and the public.

Damono [4] argues that the phenomenon of the emergence of the sociological approach to literature is inseparable from the assumption that literature deals with the human world or the symbolic world that refers to human life. Literary works are the products of authors who live in a social environment. Thus, literature is an author's imaginative world that is always associated with social life. Author as a member of society, born, raised, and received education in the midst of social life. Therefore, whether we realize it or not, the author has played his role as a member of society.

The author through his work tries to reveal the phenomena of human life, namely various events in this life. This can be understood because literary works contain notes, records, fiction, and predictions of human life. Thus, in turn, literary works often contain social facts. In fact, Grebstein quoted by Mahayana [3] states that literary works can reflect sociological developments or show subtle changes in cultural character.

In this regard, literary works in the form of novels are mostly closer to the description of social life compared to literary works in the form of poetry. The conflicts contained in a novel are a picture of the tension between the individual and the individual, the social environment, and nature. In fact, these tensions are often seen as a reflection of people's lives in which the cultural roots and spirit of the era are also contained.

In this study, Ian Watt's sociological theory of literature is used. Sociology of literature is a literary approach that considers societal aspects [4] Ian Watt revealed in his essay entitled that there is a reciprocal relationship between writers, literature, and society. Ian Watt uses three conceptual approaches in identifying meaning in the text, including the social context of the author (writer), literature as a reflection of society (literary work), and the social function of literature (society) [4].

Among the literary genres that are considered the most dominant in presenting the social elements of a society are literary works of prose, especially novels. According to Ratna [5] this is caused by several things including: (1) the novel presents the most complete elements of the story, has the most extensive media, presents the most extensive social problems; (2) novel language tends to be everyday language, the language most commonly used in society. Therefore, novels are said to be the most sociological and responsive literary genre because they are very sensitive to sociohistorical fluctuations.

Novel is one type of literary work that is interesting to study. This study is intended not only to reveal the aesthetic value of the bonds between the building blocks of the literary work, it is also hoped that the positive values contained therein can be revealed. Through a novel, the author can provide valuable lessons to readers in the form of messages that are inserted through a series of stories that are packaged in an integrated manner in a beautiful story. These messages can be conveyed through values that are essential for human life, such as educational, religious, moral, social, and so on. Thus, readers can get two benefits after reading a novel, namely aesthetic benefits and didactic benefits.

The sociology of literature study of Tere Liye's novel About You was carried out with the following considerations: First, the novel About You by Tere Liye is a very good novel and contains a complete story. This novel is not only a literary novel and story novel, but also a life journey novel. The novel About You by Tere Liye voices moral, exemplary, and social solidarity that has the potential to enlighten the reader's conscience. This novel is expected to be able to contribute to social change or the process of moral enlightenment in a better direction. An interesting problem to study in this research is the sociological aspect contained in it. Sociology of literature is always related to the social and cultural conditions of society.

Second, Darwis or better known by his pen name Tere Liye is an Indonesian novelist who is very productive in producing phenomenal works. Tere Liye has a distinctive characteristic of always wearing $\mathrm{T}$ - 
shirts, skullcaps, sweaters, and flip-flops. Some of her works that have been adapted to the big screen are Hafalan Prayer Delisa and Angel-Angel Heaven. Even though he can achieve success in the world of Indonesian literacy, writing stories is just a hobby for him because he still works as an accountant in an office every day.

Tere Liye's works are in great demand by people both in Indonesia and abroad. His physical works are considered to be able to build the soul and foster the enthusiasm for achievement of the readers. His authorship background which is always illustrated in each of his works is a special attraction to reinforce the impression that he is a novelist consistent with his life principles who always rely on the values of truth that he has believed. Third, studies from the extrinsic point of view of a literary work are studies related to the external structure of literary works. Extrinsic aspects of literary works are elements that are outside literature, but also influence the presence of a literary work. These external elements can be in the form of socio-economic factors, cultural factors, socio-political factors, religious factors, and values adopted by the community. Sociological studies of literary works are literary studies that take into account the importance of the relationship between literature and society. As a relatively new discipline, this sociological approach needs to be developed in order to find the relationship between public literature, and to prove that literary works are not born from a cultural vacuum.

The novel About You by Liye [6] has the advantage, namely that the elements of the story contained in the novel About You are very complex, ranging from stories of love, family, friendship to work. The way the author arranges a storyline that can carry the reader's imagination and emotions across dimensions between ages, the era in question is the era of Sri Ningsih's life and today. This novel raises the image of a tough woman who lives modestly from birth to the end of her life. It is told that a lawyer from the greatest law firm in England got the task of completing a will on behalf of Sri Ningsih, an Indonesian woman who died in a nursing home in Paris, France. The search for the trail began

Sri Ningsih's life in order to find a legitimate heir. [6] unpredictable storyline presents endless emotional games. The strength of the novel About You is that the research conducted by Tere Liye on the issues of inheritance rights, law, and community life in the cities of London, England, and Paris are so complex that there is no confusion in the story line. Tere Liye told me as if she had experience enforcing the law in these cities.

In this study, the researcher discusses the author's social context and the socio-cultural elements contained in Tere Liye's novel About You. One of the novels that describes social values is the novel chosen by the researcher, namely Tere Liye's novel About You. Tere Liye's novel About You describes the social attitudes shown by the main character, Sri Ningsih. One of Sri Ningsih's social attitudes is caring for others. This can be seen from the snippets of events in the novel, namely when Sri Ningsih gave food to people in need. At that time, Sri Ningsih was selling fried rice using her wheelbarrow. One day, I was standing in front of his cart, very hungry. Mother Sri waved her hand, telling me to come closer. He gave me a full serving of fried rice. Since that day, I lived with him at Pasar Senen, studying and working with him. That is the reason the writer chooses social values as an aspect that needs to be studied, because in this novel, it describes these values, both implied and explicit.

Based on these reasons, the researcher formulated the problem (1) What is the social context of the author in Tere Liye's novel About You? And (2) What are the socio-cultural elements reflected in Tere Liye's novel About You? Purpose In this study are (1) To determine the social context of the author in Tere Liye's novel About You. (2) To determine the socio-cultural elements reflected in the novel About You by Tere Liye. In conducting research, the author using the sociological theory of literature. According to Liye [6] reveals that the approach to literature is considering these societal aspects by some writers is called the sociology of literature. In view (Faruk, 1994: 4) the sociology of literature is a formless, poorly defined discipline, consisting of a number of empirical studies and a variety of somewhat more general theoretical experiments, each of which only has similarities in terms of relating to society.

Wellek [7] divide the sociology of literature study into three classifications, namely: 1.) Author sociology, writing profession, and literary intuition. ideology of the author who is involved in various author activities outside of literary works. The author is a citizen of society, he can be studied as a social being. 2.) The sociology of literary works which questions the literary work itself and those related to social problems, which is the subject of its study or what is implied in the literary work and what which is the goal. This approach commonly used by sociology studies literature as a social document. 3.) The sociology of readers and the social impact of literature. The author is influenced by and influences society, art not only imitates life but also shapes it. 
Based on these reasons, the researcher formulated the problem (1) What is the social context of the author in Tere Liye's novel About You? And (2) What are the socio-cultural elements reflected in Tere Liye's novel About You?. The objectives of this study were (1) To determine the social context of the author in Tere Liye's novel About You. (2). To find out the socio-cultural elements reflected in Tere Liye's novel About You. In conducting research, the author uses the sociological theory of literature.

\section{Method}

The method in this research is descriptive method. Moeleong [8] states that descriptive research can find facts and data from various sources or types. The data was obtained by taking raw data that the author obtained from Tere Liye's novel About You, which was filtered first, by scanning the views of other characters in the story in the form of quotations for words, phrases and sentences of the character Sri Ningsih. Then from the results of the data that the author has obtained, the authors describe it in words or sentences and not in the form of numbers or make calculations.

This study uses a qualitative method. The data source in this research is Tere Liye's novel About You, published by Republika in October 2016 with a total of 524 pages. The data in this study are sentences or utterances that contain social values. The data collection technique in this research is literature study technique. Literature study is carried out to obtain materials and information related to research such as books, articles, other documents related to research. The data analysis steps used in this study were: (1) reading and understanding Tere Liye's novel About You; (2) creating a story synopsis of Tere Liye's novel About You; (3) describe the facts of the story related to the social values contained in the novel About You are the work of Tere Liye; (4) identifying social values contained in Tere Liye's novel About You; (5) analyzing the social values identified in Tere Liye's novel About You, and (6) making conclusions.

According to Arikunto [9]"Descriptive research is a research method that seeks to describe and interpret objects in accordance with what they are". This research analyzes and describes the data that the author got so that the data that has been found can provide an overview of the image of the character Sri Ningsih in Tere Liye's novel About You so that the descriptive method in this study can be used so that the objectives of this study can be achieved. The form of qualitative research was chosen because the author analyzes sentences or utterances contained in the novel About You by Tere Liye and does not contain elements of numbers, so that the form of qualitative research is considered capable of analyze this research. According to Sugiyono [10]"Qualitative research is research in the form of descriptions and does not use numbers games or does not go through statistical procedures"

\section{Results and Discussions}

The events in the novel About You by Tere Liye have been discovered by the author of the facts of the story relating to the social context, namely as follows. This study uses the structuralism theory of Robert Stanton so that we know more about the relationship and content of a story so that we know the meaning of the story as a whole. In this structuralism analysis, the researcher focuses on the theme, the facts of the story and the mandate because these three elements are interconnected with the structure of the novel to be studied.

In writing a literary work the theme must be determined in advance so that the storyline can be stated in the literary work. Based on this statement, a theme can also be interpreted as the core or center of a literary work. Based on the theory and explanation above, the theme in this novel is the life struggle of a woman who is strong, tough, never gives up and is patient in facing various trials. This story tells of the struggle of women who started from dark times until their heyday until their death. This is evidenced in the following quote: "We had no idea that Sri Ningsih's mother had just traveled hundreds of kilometers from London all night. He .... He was penniless, hitchhiking from one car to another. Including when crossing the English Strait, he took a fishing boat, because the ferry did not want to carry passengers without a ticket. Arriving in mainland France, he returned by car after car, until finally arriving at the outskirts of Paris" [6].

The violent incidents contained in Tere Liye's novel About You are seen in the character Sri Ningsih. In the character Sri Ningsih, it can be seen in the novel that she as the stepson of Nusi Maratta experienced violence. The violence experienced by Sri Ningsih was physical and psychological violence. Physical violence can be seen, namely Nusi Martta as her stepmother, often hitting Sri Ningsih with rattan. Meanwhile, Sri Ningsih's psychological violence was when she was called by her stepmother as an unlucky child! Child who is cursed. As seen in the following quote. 
"How many times do I have to say, huh? Nusi Maratta shouted, her face bright red. Sorry mom. I accidentally. Sri was trembling with fear. Where are your eyes put? Nusi Maratta grabbed the long rattan on the table. Sri was about to step back, but her legs seemed to be moved heavily. Do you think the price of groceries is cheap? Free? Nusi hit the rattan, hit Sri's arm badly. The little girl moaned softly. One time. Twice. Three times. Mop all over the floor, or tonight you sleep outside! No dinner for you.

Nusi barked violently, after being satisfied to hit her stepson. " (Liye, 2016: 103-104) "You know why your father drowned in the sea, huh? Do you know?

Sri did not answer

It's because of you, damn boy! The cursed child.

Your mother! Remember your mother? She died giving birth to her cursed child. And after that? Your father died just wanting to buy new shoes for you. You brought this whole family bad luck. You make other people die." [6]. The quote above explains that the character Sri Ningsih experienced physical and psychological violence by her stepmother.

In characterization, there are also features or characters that can cause conflict in a story. There are many characters that are told in the novel About You by Tere Liye. There are main characters and additional characters. As the main character, namely Sri Ningsih and an additional character, namely Zaman Zulkarnain.

The background contained in Tere Liye's novel About You is: place setting, time setting, and social setting

1. Setting discusses the location of the event being told. The setting for this novel is Bungin Island, Jakarta, London, and Quay d'Orsay.

2. Time setting is the setting that explains when the events being told occur. In Tere Liye's novel About You, the time setting does not explain when it happened. The author recounts these events through the character's confession in various dialogues. There are various time settings that tell at a certain time but are not used as a reference for the author, because by telling through dialogue the writers can determine the events that are happening. The time setting occurred in 2016 when the story was told.

3. Social background, namely the setting that explains the behavior of the social life of the community in a place that takes place in literary works. The social background contained in the novel About You, Tere Liye's work is a Tasyakuran event and traditional marriage in accordance with the social community.

Patience is an attitude of holding back emotions and desires, and enduring difficult situations without complaining. This attitude is an example of positive social values. Sri Ningsih patiently endured what had happened to him. He endured all the atrocities that had been committed by his stepmother. He also endured hunger for one day and one night. However, he was encouraged to accept this fact. Make peace with all the problems he faces. As seen in the following quote.

"Sri squeezed her fingers. Her eyes are wet. He's so hungry. Especially after struggling to get clean water on the other side. Didn't the stepmother want to pity him just a little? Didn't her mother care for him just once? Sri bit her lip, immediately chased away the bad thoughts that crossed her head. It's okay, it's okay ... Sri looked down to persuade her heart, at least tilamuta tonight slept on her stomach full. It is more than enough. Previously his father told him, apart from always obeying his mother, that he should look after Tilamuta. "

Wish me strong through everything, Nur. Tonight, writing this letter while crying, my heart feels lighter. Tomorrow, I promise to start from scratch".

The two quotes above explain that Sri Ningsih is always patient face every problem he experiences. First, the cruelty of her stepmother, she is always patient with what her stepmother has done. Second, he tried to be patient with his car rental business being destroyed by the social unrest that occurred in 1974 or often known as the Malari Incident (Malapetaka 15 January).

Sri Ningsih's attitude includes positive social values, such as not opposing or arguing with parental orders as children. As is common today, many children argue with their own parents. As stated in the following quote:

"You take clean water across the island right now! I do not want to know. Nusi Maratta grabbed the empty jerry can, threw it at Sri, 'and Tilamutta entered the room! What are you doing in the kitchen with this cursed child! "Tilamutta ran out of the kitchen. Leaving Sri who bit her lip. Hurry up, Sri!!! What are you waiting for? Nusi grabbed a rattan stick, threatened. There is no choice for Sri, she has to carry out her stepmother's orders, she grabs the jerry can" [6]. 
The quote above demonstrates Sri Ningsih's devotion to his stepmother. He always carried out his stepmother's orders. Sri never once tried to say no. Sri Ningsih's attitude includes positive social values, such as not opposing or arguing with parental orders as children.

Literary works have many types and forms of moral messages that will be conveyed through his work, for example novels. In the novel, there are many moral messages conveyed through the character's story, character and treatment of the character depicted. The moral values contained in the Novel About You by Tere Liye are the relationship between humans and themselves, human relations with other humans in the social sphere, human relations with the natural environment, and human relations with God.

These problems can relate to issues such as self-existence, self-esteem, self-confidence, fear, death, longing, revenge and various problems related to oneself. The moral value of human relations with oneself found in the novel About You works Tere Liye covers. Honesty, Never Give Up, Have Good Thinking, and Patience.

In the social environment we must relate to other people in our daily activities to do good to others. The moral values of human relationships with other humans in the social sphere contained in this novel include Helping to Help, Keeping Promises, Obeying parents, and Love for others.

The relationship between humans and the natural environment can be proven by praising the beauty of nature that God has given and should be grateful for its existence. As can be seen in Tere Liye's novel About You, praising the natural beauty of God's creation.

\section{Conclusions}

Based on the results of research conducted by the author on Tere Liye's novel About You, it can be concluded as follows: The fact of the story in this novel is violence, especially psychological violence, where the character Sri Ningsih is often seen as an unlucky child, a child cursed by her stepmother. In such a situation, Sri Ningsih responded by forgiving everyone who hurt her, willing to give in, and swallow all the pain that was done by others to her. However, for other characters, it is not entirely like that. Novel About You tells the story of Sri Ningsih who forgives people who hurt her, tries to give in, and swallows up every bit of her pain. But other figures are not like that, only some of Sri Ningsih's goodness is owned. Actually, the author suggests to the reader to become "You" like Sri Ningsih. Such are the social values offered by Tere Liye.

The moral values in the novel About You, namely honesty, never give up, prejudice, patience, help, keep promises, uphold the truth, obey parents, love others, praise the natural beauty of God's creation, worship and ask for forgiveness.

\section{References}

Waluyo, H. J. (2002). Drama: Theory and Teaching. Yogyakarta: PT. Hanindita Graha Widya.

Al-Ma'ruf, A. I. (2007). Methods of Writing Scientific Papers. Yogyakarta: Pilar Media Yogyakarta.

Mahayana S. M. (2007). Ekstrinsikalitas Sastra Indonesia [Extrinsicality of Indonesian Literature]. Jakarta: Raja Grafindo Persada.

Damono, S. J (1978). Sosiologi Sastra sebuah pengantar ringkas [Sociology of Literature a concise introduction]. Jakarta: Pusat Pembinaan dan Pengembangan Bahasa.

Ratna, N. K. (2010). Teori, Metode, dan Teknik Penelitian Sastra [Theory, Methods, and Literary Research Techniques]. Yogyakarta: Pustaka Pelajar.

Liye, T. (2016). Tentang Kamu [About You]. Jakarta: Republika

Wellek, R. \& Warren, W. (1989). Literary Theory. Jakarta: PT Gramedia.

Moeleong, L. J. (2014). Metodologi penelitian kualitatif [Qualitative research methodology]. Bandung: PT Remaja Rosda Karya.

Arikunto, S. (2010). Research procedures. Jakarta: Rineka Cipta.

Sugiyono. (2014). Educational Research Methods with Quantitative Approaches, Qualitative, and $R \& D$. Bandung: Alfabeta.

Sutopo. (2014). Kepemimpinan dan Supervisi Pendidikan [Educational Research Methods with Quantitative Approaches, Qualitative, and $R \& D]$. Malang: Bina Aksara. 